\title{
The Concept of Sufi I'rab by Abdul Qadir al-Kuhany in Understanding the Salat Movement
}

\author{
$1^{\text {st }}$ Rizki Fathul Huda ${ }^{1}, 2^{\text {nd }}$ Iik Arifin Mansurnoor $^{1}$, Andi M. Faisal Bakti ${ }^{2}$ \\ \{rizki3803@gmail.com¹, iik.arifin@uinjkt.ac.id ${ }^{1}$, andi.faisal@uinjkt.ac.id²\} \\ UIN Syarif Hidayatullah, Islamic Studies Department, Jakarta, Indonesia ${ }^{1}$, UIN Syarif Hidayatullah, \\ Da'wa and Communication Department, Jakarta, Indonesia ${ }^{2}$
}

\begin{abstract}
Salat, Islamic praying, is considered as worship as well as communication between those who pray with Allah almighty. The main point in communication is the connectedness between two individuals who are able to cause feedback and positive impacts. Therefore, by understanding the movements and readings in Salat can bring people who pray to sink further in communication with God Almighty. This is interesting to reveal how the meaning of the Salat movement in the perspective of the I'rob Sufi by Abdul Qodir Al-Kuhany. This study uses a qualitative approach with interpretation methods. Researcher interprets the concept of the i'rab Sufi by Abdul Qodir al-Kuhany in interpreting the Salat movement. Salat has at least 4 main movements, namely: standing, bowing, prostration, and sitting. These 4 movements have links to the meanings of the four types of I'rob which are explained by Abdul Qodir Al-Kuhany.
\end{abstract}

Keywords: al-kuhany, i'rab, salat movement, sufi.

\section{Introduction}

One of the special characteristics of the worship of the followers of the Prophet Muhammad is Salat. Even the five daily Salat are compulsory and most important worship among fasting, alms, hajj, and other worship. Because, the obligation to pray for Muslims is a provision that was delivered directly by Allah to the Prophet Muhammad when the event of isra' mi'roj. While the obligation of other worship is conveyed by God through His revelation in the Qur'an.[1]

Salat in language means the prayer of a servant to his god. In prayer, there is definitely a process of communication between him and his god in asking for all the intentions. Communication in prayer requires special conditions, low self-esteem, and purity of intention to generate strong power of prayer. [2] Through salat, Allah introduces Himself and often gives instructions to His servants. Even salat becomes a shock tool for the hearts of His servants who forget Him, the conditioning of the hearts of those who love Him, and a place to taste the enjoyment of unity between the servant and Allah Almighty. [3] The obligation of salat is proof that Allah raised the glory of the followers of the Prophet Muhammad. Because, through salat intertwined the union between Allah and His servants. At the time of the people before the prophet Muhammad had not been required to salat 5 times in one day. Even the bodies of the people are prescribed to be holed up before they are buried. 
Surely salat is not only the movement of limbs and readings that come out of oral course. However, the essence of salat is the salat of the heart. Because, sacred communication occurs in the heart. If the heart performs salat well, then it is also good that the salat of other body parts. If the heart does not pray well, then in vain all the other limbs in vain. [4] Salat is the place of one's soul and is the ritual that Muslims miss the most. Because, in prayer is the meeting with Allah swt. In fact, the prophet Muhammad himself was so desperate to salat, to the point that tears of longing when bilal had echoed the call to salat. [5]

Therefore, the term khusyu' appears in salat. Khusyu' in the salat takes place in the hearts of those who practice salat. If the heart has reached khusyu', then khusyu' can appear and lead through the limbs, and faces of people who pray, not vice versa. Because, the heart is upstream, while the limbs and face are downstream. If khusyu' only occurs in the limbs and face only, then this khusyu' is called khusyu' nifaq. Khusyu' in salat can achieve various benefits. Just like the fusion of sins, abundant merit, the fulfillment of all prayers that are offered, and able to keep people who pray from all heinous and evil deeds. [6]

In the perspective of tasawwuf, Salat is a vehicle for someone to navigate the journey to the presence of Allah. With purity capital was born in the form of body, clothes, and place of salat that was protected from all najis and hadats. And inner purity in the form of a pure heart, then one can feel a beautiful encounter with Allah. So that it creates a condition of ittihad between a servant and Allah Almighty, until nothing crossed his mind and heart except Allah alone. [7]

Of course it is not easy to reach the fabric of a pleasant and solemn communication between a servant and Allah in his salat. Because, in the condition of both eyes open, verbally saying various sentences and prayers, as well as limb movements, a person who is prayed is required to focus on Allah alone. In fact, the layman when dhikr with the sentence tahlil, tahmid, prayer beads, or takbir in a state of sitting and closing his eyes still often his heart and mind lost focus on God Almighty. Therefore, an understanding of the meaning of the prayer movement is very interesting to study. So that it can produce scientific treasures to help the heart of a servant in diving into the pleasure of communicating with God Almighty.

Muslim intellectuals have long explained through his writings the philosophical meaning of the movement and prayer readings. Just name it Ibnu al-Qoyyim al-Juziyyah in his book Asrar al-Shalah, and Ahmad Khoiri al-'Umri in Fiziya' al-Ma'ani. And it has been practiced by Sufis, both in their daily prayers and dhikr which always perform istihdhor al-qolb. Most of them, display the philosophical and sufistic aspects in interpreting the movements and reading prayers. Interesting to see from the other side. One of them is the merging of Sufistic linguistics.

We can said, that Tasawwuf and Salat have the same goal. It is communicate directly and get the closest place to the presence of Allah Almighty. Of course with the concept of tasawwuf, it is easier to uncover the philosophical meaning of the Salat movement. So that it can make a Muslim more appreciate in every Salat movement that he does. [8] Tasawwuf also has a close relationship with nahwu. Both of them manage error avoidance. It's just that the object of tasawwuf is a matter of heart and spirit, while the object of study of nahwu is a sentence in a text.

And then comes al-Qusyairi, who explain the study of nahwu not only has to do with evaluating errors in language (lahn) or determining I'rob at the end of each word. However, Nahwu can also play a role in relation to a servant's behavior. Because, nahwu also has a philosophical meaning that plays a role in guarding the heart from despicable qualities. So that in the world of linguistics also appears a good connection between the heart of a servant with Allah Almighty. [9] 
Al-Qusyairi is one of the figures of tasawwuf who inspired Muslim intellectuals afterwards in connecting between nahwu and tasawwuf through his book Nahw al-Qulub. They are Abdul Qadir al-Kuhany in his book Munya al-Faqir al-Mutajarrid wa Saira alMurid al-Mutafarrid, Ibnu Ajibah write Mukhtasor Ibnu Ajibah 'ala Matni al-Jurumiyyah, Ibnu Maimun in his book al-Risalah al-Maimuniyyah and Nur Iman in his book al-Sani alMatalib. The last name is one of the intellectuals originating from Yogyakarta, Indonesia. Nahw al-Qulub is a representation of al-Qusyairi's love for these two kinds of knowledge. He gave the message that the science of nahwu and Sufism reinforce one another and not conflict. [10]

By taking inspiration from Abdul Qadir al-Kuhany about the concept of I'rob Sufistik which he explained in his work. Researcher intend to make it a "knife" to analyze and dissect what the Sufistic meanings of salat movements. This paper begins by explaining the concept of I'rob and its classification in the field of study in nahwu. Through the nahwu sufistik approach, this paper is expected to explain the Sufistic meaning of the prayer movement. So that it can be applied in the salat for Muslims.

\section{I'rab}

I'rob in language is derived from the word عرَبَ which means fluent in speaking. [11] In nahwu, i'rob means the change at the end of every word in Arabic is caused by the influence of the incoming 'amil. It is so called, because i'rob regulates eloquence and prevents someone from speaking errors (lahn) written or spoken. [12]I'rob is a result of the influence of amil who makes a word punished by marfu', manshub, makhfudh, or majzum. Antonym rather than I'rob is bina' which means no words can be affected even though they are influenced by various types of 'amil. [13] I'rob is a major study in nahwu science. Because, nahwu all forms of words, sentences, or numbers, can be identified textually through the concept of i'rob. I'rob is always presented in the early chapters by classic nahwu books, such as Syarah Jurumiyyah, Nadzam al-Imrithi, and Alfiyyah Ibnu Malik. Even in learning nahwu at Islamic boarding school (pesantren), there are often contests for reading classic books (musabaqoh qiro'atul $k u t u b$ ), and the orientation is always at the i'rob point. Through i'rob we can identify the position of a word in a sentence, subject, predicate or object.

From the explanation above, it turns out that there is confusion in the definition of i'rob. First, I'rob is defined as the process of changing the final condition of words caused by amil entering, and marked with various signs in the form of letters or predetermined letters. This change occurs abstractly and cannot be seen. This definition considers I'rob to be in a position in the final word change process. Second, I'rob is defined as the result or result that occurs after the final change of words is caused by the entry of amil. This definition assumes that I'rob is in a position after the change has occurred. Third, I'rob is a concept that functions to determine the position of a word in a sentence so that there is no error meaning. For example in determining the position of subjects (fail), mubtada', objects (maf'ul), or naib al-fail. In the end, it is known that I'rob is a term for determining the position of words in a sentence through the classification of words in several kinds of I'rob which can be identified through the signs of I'rob itself. And in the end, this determination and classification occurs due to amyl or factors that change the word of a word. [14]. 
I'rob in the scope of nahwu has 4 types of classification, namely rafa', nashab, khofdz, and jazm. I'rob rafa', nashab and khofdz are specific to noun (isim), while verb ( $\left.f i^{\prime} i l\right)$ can have I'rob rafa', nashab and jazm. [15]

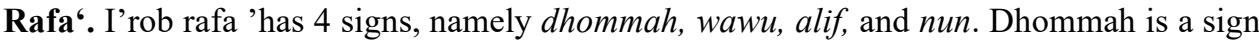
of rafa' for isim mufrod, jama' taksir, jama' muannats salim, dan fi 'il mudhori' shohih akhir. Wawu is a sign of rafa' for jama' mudzakkar salim and asmaul khomsah. Alif is a sign of rafa' for isim tasniyah. And nun is a sign of rafa' for af'alul khomsah. Through the signs I'rob rafa' a word can be identified its position in the sentences. Such as subject (fail), naib al-fail, mubtada', khobar, isim kana, khobar inna. Through the signs I'rob, many descriptive (na'a)t, attractions ('athof), confirmatives (taukid), dan substitates (badal) can be identified their owner. [16].

Nashab. I'rob nashab has 5 signs, it is fathah, alif, kasrah, ya', and throw away nun letter. Fathah is a sign of nashab for isim mufrod, jama'taksir, and fiil mudhori which is influenced by Amil Nashab. Alif is a sign of nashab for asmaul khomsah. Kasrah is a sign of nashab for jama' muannats salim. Ya' is a sign of nashab for isim tasniyah and jama' mudzakar salim. And throw away nun letter is a sign of nashab for af'alul khomsah. Through the signs I'rob $n a s h a b$ a word can be identified its position in the sentences. Such as objects (maf'ul), original noun (masdar), adverbial of time (dhorof zaman), adverbial of place (dhorof makan), cicumstansial (ha)l, distinative (tamyiz), excluded (mustatsna'), noun of "no" (isim laa), noun of called (munada), predicate of to be (khobar kana), noun of "indeed" (isim inna). [16].

Khofdz. I'rob khofdz has 3 signs, it is kasrah, ya', and fathah. Kasrah is a sign of khofdz for isim mufrod munshorif, jama' taksir munshorif, and jama' muannats salim munshorif. Ya' is a sign of khofdz for asmaul khomsah, isim tasniyah, and jama' mudzakkar salim. While fathah is a sign of khofdz for isim ghoiru munshorif which has been influenced by illat ghoiru munshorif. [17]. I'rob khofdz is influenced by both idhofah and the khofdz letters. The letter khofdz influences the meaning rather than isim or fi'il. The letter khofdz can function as a preposition. [18] Therefore, the letter khofdz has the function of connecting between the two words in front and behind the letter khofdz. Like the letter so which shows the beginning relationship from the side of the place or shows the meaning of the involvement of a word in a classification. [19].

Jazm. I'rob jazm has 2 signs, it is sukun and throw away letters. Sukun is a sign of jazm for fiil mudhori' shohih akhir. While throw letters divided into two, namely throwing letters noun is a sign of text for afalul khomsah. And throw illat letters into a sign for the mudhori fiil ending in illat letters (الو، و ي (15]. I'rob jazm only belongs to the fiil mudhori'. I'rob jazm does not affect the meaning of fiil mudhori' in terms of his position in the sentence. It's just he influences the meaning of the relationship between the fiil mudhori' and his subject (fail) or objects (maf'ul). [20].

Sufi is a term for people who study Sufism. In his understanding, tasawwuf is a study of noble morals, purity of heart, and self sufficiency only with God Almighty. Tasawwuf is considered different from philosophy which can be formulated into a branch of science. Because Sufism is a representation of the experiences of the Sufis in wading the way to purify their hearts, and eliminate dependence on other than Allah. The experience of the Sufis is certainly and totally different. Therefore, it cannot be formulated with certainty how the concept of the journey leads itself towards Allah. [21]

Tasawwuf is oriented towards issues of purity of the soul in improving relations with fellow beings and Allah. Therefore, the classic books that discuss tasawwuf often begin with the chapter repentance to Allah and contain various karmic arrangements in associating with fellow beings. Of course it can be understood that the orientation of nahwu with tasawwuf is 
very different. Nahwu is text oriented while tasawwuf is heart oriented. The difference in the object of study of the two disciplines of science is apparently not a problem for Abdul Qadir al-Kuhany. With brilliant, he gave a different understanding about one of the objects of study of science namely i'rob.

The full name is Abdul Qadir bin Ahmad bin Abi Jayyidah bin Ali bin Abdul Qadir, and he is often called by the chewing name (kunyah) Abu Muhammad al-Kuhany from the city of Fez, Morocco. He died in Medina in the month of safar in $1254 \mathrm{AH}$, and was buried in the tomb of Baqi'. [22]

He was born in $1177 \mathrm{H}$, he grew up, studied, and taught in his birthplace, Fez. Until finally when he performed the pilgrimage, he met with the pious and hadith experts in the Holy Land. He explored the science of hadith, until his name was famous because of his duo book syarh iftitah shohih bukhori, dan syarh khotimah shohih bukhori. [23] Al-Kuhany had a chance to learn from the famous Ulama at that time including Abu Hamid al-Darqawi, Abdullah bin Abd al-Rahman Siradj who was the mufti of Mecca, and Abdullah al-Sanusi. The majority of his students came from his native land, such as al-Tholib al-Siradj al-Fazy, Abd al-Karim bin Abi al-Barakat al-Majdzub al-Fazy.[23] Al-Kuhany's works are not only focused on Sufism. But he also bequeathed his work in the fields of hadith and nahwu. Such as syarah ifttitah al-bukhori, syarah khatimah al-bukhori, munya al-faqir al-mutajarrid wa saira al-murid al-mutafarrid, syarah al-hikam al'athoiyyah, imdad dzawi al-isti'dad ila ma'alim al riwaya wa al-isnad. [23]

Al-Kuhany observes from the side of tasawwuf, i'rob is the change in behavior caused by internal and external influences that enter the heart of a servant. So that the heart of a servant sometimes occupies the qobdh position, which is feeling narrow and difficult. And sometimes in a basth position or feeling of space and beauty. [22] I'rob in the science of nahwu occurs in various kinds of words in Arabic. I'rob also happens to a variety of people's hearts. So sometimes the heart is in the position of rafa', nashab, khofdz, or jazm.

Rafa. Rafa 'in the concept of Sufism is the promotion of the degree of glory of someone in the sight of Allah. Factors that can increase the degree of glory of the heart is because the heart has been able to know God Almighty by always obeying Him. The heart of someone who is always associated with Sufis and saints also can raise the degree of glory. [22]. Rafa' of heart in the concept of tasawwuf according to al-Kuhany is marked by the following signs: Dhommah, literally means combination. Al-Kuhany means that the promotion of a person in the sight of Allah can be realized if he joins in a spiritual attitude with a teacher who is able to lead him to the presence of Allah. Of course by way of serving, love, and respect and follow the direction of the spiritual teacher. $W a w u$, wawu as a sign of someone's promotion in the sight of Allah is to fall in love with Him. So that no longer the name and essence that crossed the mind of a servant except Allah Almighty. This condition of falling in love with God is called mortal (fana'). Alif, alif meant by al-Kuhany is one-sided. In the context of tasawwuf, the purpose of one is that someone who wants to move up in rank, he must set a goal in his life only to Allah. His love for fellow creatures must not exceed his love for Allah. This can be realized by asking God Almighty through dhikr qolbi and lisani which is always done at any time. Nun, Nun means that people who try to get close to Allah, on their way, they will get nur or light of pleasure from Allah. Until he no longer needs to bother on his spiritual journey. Because, God himself who would approach him by giving various lights of pleasure in the world in the form of abundance of favors, grace and convenience. And the light of pleasure in the afterlife in the form of a direct meeting with Allah.

Nashab. Nashab in the concept of tasawwuf is the calm and balance of a person in dealing with things that are beneficial or detrimental to him. In another sense, nashab means 
the blessing and surrender of one's heart to all the provisions that Allah predestined. This is the station of rangers who have a calm soul and ma'rifat billah. [22]. So al-Kuhany gave an explanation of the signs of his heart. Namely as follows: Fathah, it is the open heart of a servant to always be ma'rifat billah. A person who has a heart, will not be shaken and trembled in the face of everything that happens. Because, he accepted all the provisions of Allah. The good things that happen he will always be grateful and he sees that Allah is behind all that. Meanwhile, bad things that happen will be a trigger in an effort to get closer to God Almighty. Alif, al-Kuhany still defines alif of the signs of the same text as alif of signs of rafa '. Versatile one in the context of tranquility of the soul is a manifestation of an attitude of trust in Allah's authority over all things. Kasrah, has the meaning of submitting and complying with all the provisions decided by Allah Almighty for everything that happens to him specifically, and that which happens in all things in general. Kasrah also means a servant who shows attitude always needs the help of Allah swt. $Y a^{\prime}$, al-Kuhany means ya' as a sense of confidence that a servant must have in all his endeavors. Belief or optimism is a form of representation of faith that is perfect. A servant who already has a confident attitude towards Allah will not feel difficult in worldly affairs. Because he is optimistic that Allah has fulfilled everything he needs. Hadzf Nun, throwing away nun letter in the perspective of tasawwuf which al-Kuhany explains is to get rid of the attitude of selfishness. Namely the exit of a servant from the mortal attitude (fana') to baqa'.

Khofdz. In the concept of tasawwuf is an attitude of heart that feels humble before God Almighty and mengangsunggakn Him. This attitude can arise if a servant feels himself stupid and does not have any strength before the Almighty. And can be trained by always avoiding all forms of immorality and avoiding the despicable desires. In another sense, khofdz also means respect for guardians and tawadhu' to fellow human beings. [22]

Jazm. Jazm in the concept of tasawwuf is to establish the heart to always strive to get wushul and hulul to Allah. Jazm means a servant who holds fast the aqeedah rope and knowledge in his journey to reach the level of billah ma'rifat. In another sense, jazm means to strengthen the heart of Allah by resolving all prejudices, illusions, delusions, and negative illusions. [22]. Signs of jazm in the concept of tasawwuf is as follows: Sukun, it is calmness like a strong mountain stuck to the earth. It does not waver even though there are various causes of doubt, it does not collapse even if it is hit by moodiness. In another sense, breadfruit also means physical constancy in the face of difficulty. Hadfzu, al-Kuhany gives the understanding that one who is steadfast in his heart will throw away everything that makes the heart dirty. So that in the heart of a servant there is no doubt and there is nothing good except to remember the name of Allah Almighty.

\section{Salat}

Salat is a ritual of worship consisting of certain readings, as well as the movements of the body and heart that are pure. Salat begins with raising the name of Allah accompanied by sincere intentions, and ends with greetings (salam). This holy ritual requires high concentration. Because, people who offer Salat are required to concentrate fully their mind and heart in establishing vertical communication with Allah Almighty even with their eyes open and various movements of changing limbs. [24] Salat that must be performed for the people of the Prophet Muhammad 5 times in one day. This 5th prayer is a gift that the Prophet 
Muhammad received from his isra 'mi'raj trip which occurred 10 years after he was appointed Prophet. Precisely on the night of the 27th Rajab. [25]

Salat in its implementation like other rituals of worship, of course, have harmony and conditions. There are differences in the number of pillars of Salat in various sources of classical books. In Mirqat Su'ud al-Tasdiq syarah sullam al-Taufiq, Muhammad Nawawi mentions that there are 17 pillars of Salat by making thuma 'ninah a separate pillar. While in Fath al-Mu'in, Zainuddin al-Malibary mentions that there are 14 pillars of Salat by making thuma'ninah a pillar that sticks to each Salat movement.

The first pillar of Salat according to the fuqaha' syafi'iyyah is intention. Intention becomes a fundamental part of various rituals of worship. Therefore, the intention is a valid benchmark or whether the rituals of worship including prayer according to the hadith of the Prophet Muhammad. Intention is the entrance of a servant to the holy dimension where he communicates with Allah. So the intention is considered important to consider in managing concentration. Because, if the initial steps of ritual worship are already in disarray, it is feared that the next step will be more chaotic so that the purpose of communication in the prayer is not reached. [26]

The second pillar in Salat is takbir al-ihram. The implementation of takbir al-ihram together with intention. It's just that takbir al-ihram is done through verbal speech, while the intention is done in the hearts of those who offer Salat. [25] Takbir means to glorify the name of Allah, while Ihram comes from the word haram. This means that takbir al-ihram is the beginning of all halal things that are prohibited. Like eating, drinking, hanging out with fellow humans, etc. Takbir al-ihram is a marker of the beginning of nothing that should be considered by those who pray, except himself and Allah Almighty. Even the most beautiful things in the world must be removed from the minds of those who offer salat.

The third pillar is standing for those who are able to carry it out. Standing in Salat is required to face the Qibla. And in it carried out the fourth pillar of Salat namely reading alFatihah. Thus, it is not valid for Salat for someone who does not recite al-fatihah according to the hadith of the prophet Muhammad. [25]

The fifth pillar is bowing (ruku') by arching your back and straightening it with your neck and head. It was intended to extend the duration of the ruku', in contrast to the sixth pillar namely iididal which was not long ago. It's not rising from the ruku' with the position straightened up again. Followed by the seventh and eight pillars of salat, namely prostration and sitting between two prostrations. Prostration is the lowest body position among all prayer movements. Because, in prostration the position of the head attached to the place of salat. The body bends before Allah Almighty full of humility before Him. Pillars of the fifth to eighth Salat above is always accompanied by thuma'ninah which is the ninth pillar of the salat. Thuma'ninah is a space that must be filled by those who pray in enjoying and living every Salat movement. [27]

Then the next pillar of Salat is more dominated by the pillars that are carried out by verbal utterance. Namely the pillars of prayer in the form of reading the final tasyahud, blessings to the prophet Muhammad, and reading greetings. The whole pillars are carried out in a sitting motion which is a pillar of Salat too. And the last pillar is the successive implementation of all the series of pillars of the Salat that have been formulated. [25] 


\section{Sufi I'rab in Understanding Salat Movements}

Abdul Qadir al-Kuhany's attention to nahwu knowledge was not only limited to wanting to give a grudge, but he connected nahwu with tasawwuf by making nahwu a path to the presence of Allah Almighty. Nahwu is a science that is used to achieve goals in language, whereas humans have different goals and steps. So, people who discuss nahwu from the oral side are called linguists, while people who discuss nahwu by heart are called sign experts. [28].

Implicitly, Abdul Qadir al-Kuhany delivered a message to people who were deep in nahwu science. First, that it is not only language that needs to be paid attention to right and wrong. However, there are greater things to consider. That is the heart, attitude, behavior, morals, and relationships with fellow humans and to Allah. Second, nahwu science is not only applied in relation to texts. However, nahwu science in the perspective of tasawwuf can also be applied in ritual worship which is a primary need for religious people.

Therefore, Salat which is a ritual of the vertical relationship between a servant and Allah must pay attention to the intent, purpose, and steps. Because, prayer without regard to the right steps, will make the achievement of goals and intentions rather than the prayer itself. In this paper, the focus of his research is on the prayer movement which is analyzed through the concept of i'rob by al-Kuhany.

It is one of the objectives of Sufism, which is to overcome the crisis of the relationship between man and his creator. Tasawwuf is one way to eliminate the disorientation of life values. When the majority of people today are more oriented to world affairs and forget their relationship with Allah. [29] Especially in the implementation of prayer, tasawwuf has an important role in terms of cleaning the liver of impurities. Because in munajat to Allah through prayer with a heart that is negligent and lapsed in the valley of doubt will be rejected and cause the wrath of Allah Almighty. [30]

The idea of the application of the concept of i'rob al-Kuhany is based on the principal movements in prayer which amount is equal to the number of kinds of i'rob in the science of nahwu. The main movements in prayer are standing, bowing (ruku'), prostration (sujud) and sitting. The researcher views the continuity in terms of the meaning contained in the concept of i'rob with the prayer movement.

Standing. Researchers view the standing movement in salat can be analyzed its meaning in terms of i'rob rafa'. Rafa' means to elevate to a high place. Of course it can be understood that standing is the highest movement position in salat. Although standing movements are the highest position in prayer, living the movement does not mean that a person feels high. Precisely arrogant feelings in a servant will automatically be rejected in this movement. Because in this movement, people who pray say takbir which has the meaning of raising and glorifying the name of Allah Almighty. There is no longer the greatest and most great being besides Him. This movement is also meaningful as follows: Dhommah, it is the attitude of uniting with Allah Almighty. This means that the standing movement which is the beginning of the prayer movement shows that the hearts and minds of people who pray are oriented only to Allah. This is in line with the movement of takbir al-ihram which is performed when standing as a "start" button eliminating all kinds of mind and heart oriented except to Allah swt. Wawu, standing movement means an attitude of love and respect for Allah. Standing is one of the attitudes of a person in respect of others, as is usually true in social life. If in welcoming guests we only respect by standing and shaking hands, of course the attitude of respect when standing in prayer has a level of respect more than respect for fellow human beings. This honor is followed by greeting Him through love for the Khaliq. Alif, alif shows 
that standing movements deny all matters other than Allah. Lafadz Allah himself begins with the letter alif. Lafadz shows the name of the one great and great. In takbir al-ihram when standing the so called names of the Almighty Allah show Himself, not the names of attributes that indicate parts of His Essence; [31]. Nun, standing movements are a symbol of the journey of a servant to reach lights (nur) from Allah Almighty. His light can be received and felt by those who pray through standing movements.

Bowing ( $R \boldsymbol{u} \boldsymbol{k} \boldsymbol{u})$ is the second movement after standing. $R u k u^{\prime}$ can be identified by using the concept of the text in i'rob sufism. In language, nashab means to straighten up. Ruku' movement is a movement that begins with bending your back to your head, then straightening it. Therefore, researchers looked at the correlation between texts and ruku, so that it is possible to interpret this movement with the concept of Nashab Sufism.

In detail, the meaning of this movement can be viewed from the signs of the I'rob texts as follows: Fathah, In the implementation of this movement body balance is needed so as not to fall down. Therefore, this movement is a symbol of balance and calmness in submitting to Allah so that he will not fall into the abyss of humiliation. Fathah implies resignation (tawakkal) which is the starting point for relying on the heart of Allah Almighty and running away from dependence on other sources of strength. Alif, alif is a symbol of the meaning of the ruku' movement and the second level after resignation, it is taslim. After resting all things only to Allah, the one who is bowing will get the result of a heart that is always indoctrinated in "one-sided". Nothing else he needs and he is looking for, but Allah. Kasrah, the third level of meaning in the ruku' movement is tawfidh which has a broader meaning than resignation (tawakkal) and taslim. Tawfidh means the attitude of human detachment from all his strengths and other outside forces. This is a form representation of sentence la haula wa la quwwata illa billah. Ya', ruku' movement which has 3 meanings of the process of heart reliance in the form of resignation (tawakkal), taslim, and tawfidh will produce a sense of confidence. According to al-Kuhany sure can appear in a person if he holds fast to shari'ah and haqiqat. Hadzfu Nun, the meaning of the last ruku' movement in accordance with the understanding of throwing away the nun letter. It is, eliminate all arrogance, selfishness, and arrogance in self. The meaning of the fifth ruku' movement is the result of the process of relying on the heart of God Almighty from resignation (tawakkal), taslim, tawfidh, and sense of confidence. Sequentially in the ruku movement 'there is a process of self-reliance of a servant to Allah swt through resignation (tawakkal), taslim, and tawfidh to cause confidence. So that it melts away all the arrogant qualities in a servant.

Prostatuion $($ Sujud $)$ is the lowest movement in prayer. Researchers view the prostration movement can be identified its meaning through the concept of I'rob khofdz. First, khofdz literally means low or down. From the language side, khofdz shows the prostration movements performed by lowering the body to the lowest position. Second, the main sign in I'rob khofdz is kasrah. It can be concluded that Kasrah is a symbol of prostration, because writing Kasrah in the text lies below the letters. In line with prostrations performed in the lowest position.

More specifically, the meaning of this movement is in accordance with the khofdz signs as follows: Kasrah, the prostration shows the humiliation of the Holy One. And the poor man (faqir) attitude in the presence of the Rich. Kasrah literally means fractions or pieces. This is a symbol that a human being is like a small plate in front of the Great. Therefore, in prostration is recommended to read subhana robbiya al-a'la which has the essence of a servant's acknowledgment that he is nothing. And only Allah Most High above all. Ya', in interpreting the prostration movement can be interpreted as a manifestation of the belief that everything in the world and the hereafter only belongs to Allah. high confidence that there is no power and 
effort other than the absolute power of Allah Almighty. Apart from that, yes 'is also one of the letters nida or call. Therefore, it is extended to extend prostration by increasing the call and prayer to Allah. Fathah, Fathah be a sign of khofdz in interpreting the prostration movement means that prostration is a movement that is possible to occur in the process of opening a servant's heart to feel the touch of affection from Allah Almighty. Fathah is a sign of khofdz for isim ghoiru munshorif, it means Allah's love is given to the servant who does not devote his life to follow the bad passions.

Sitting is the last basic movement in prayer. In this movement there are other pillars of prayer in the form of reading the final tasyahud, blessings to the Prophet Muhammad, and greetings. Sitting is carried out based on the place of prayer in a permanent and calm. Therefore, researchers view sitting in Salat can be analyzed its meaning through the concept of i'rob jazm. Because, jazm literally means "determination".

The meaning of the sitting motion can be seen from the signs of jazm as follows: Sukun, seated movements contain the meaning of breadfruit, which is calm and peace. In sitting is a symbol of physical calm in dealing with all the hard work and peace of the soul of the person who prays. Because, he has gained a variety of pleasures ranging from union with God, getting lights (nur) from God, love for God, opening hearts in ma'rifat to God, enjoyment of surrender to God, to the touch of God's love. Ibn 'Athoillah explained through his book Taj al'Arus, that people who offer prayers without producing breadfruit and solemnity' are like being hit by dust. Even though in front there is misk oil. Because, praying is like "kongkow" with Allah, the most delicious of Fragrant, but what is obtained is not a fragrant spark, but exposure to dirty dust. [32]. Hadzfu, sitting movements have the meaning of the ultimate movement of the process of cleansing the soul that is in a series of prayer movements, as well as being a sign of function rather than prayer itself. Hadfzu means the sitting motion is a symbol of the elimination and elimination of all liver diseases. So that a servant after exiting prayer no longer needs him except Allah Almighty, there is nothing else he fears except Allah Almighty, and there is no longer any doubt in the power and help of Allah. This will make the prayers feel homesick to return and continue to carry out the prayer. So, the function of prayer as a deterrent from heinous and evil deeds will be well realized.

\section{Conclusions}

From the description above, it can be concluded that the movements in prayer can be reduced to 4 main movements. It is standing, bowing (ruku'), prostration (sujud), dan sitting. Understanding these 4 main movements can be done through the concept of the I'rob Sufism formulated by Abdul Qadir al-Kuhany in his book Munya al-Faqir al-Mutajarrid wa Saira alMurid al-Mutafarrid. Although this concept moves in the realm of linguistics and Sufism, but this concept can be used as a "knife of analysis" in skinning the meaning of the prayer movement. Because prayer is not only engaged in the study of jurisprudence. Deeper prayer is part of the study of Sufism.

First, the standing movement has the meaning of the initial process of joining oneself to Allah through the love of Him and insisting on the goal only to Him until getting light (nur) from Him. Second, the ruku' movement means a process resignation (tawakkal), taslim, tawfidh, and self confidences to Allah swt to avoid being arrogant, 'ujub, dan selfishness. Third, the prostration (sujud) movement has a symbol of humility before the Almighty, and confidence in His power. Giving rise to the opening of a servant's heart to receive a touch of 
his affection. Fourth, the sitting motion has the meaning of physical tranquility and peace of the soul after obtaining various previous pleasures. Until the realization of the function of salat in the form of avoiding heinous and evil deeds.

Acknowledgments. Many thanks are due to Graduate School of Islamic University Syarif Hidayatullah Jakarta. Especially Prof. Dr. Jamhari, MA, Prof. Dr. Didin Saepuddin, MA, Prof. Dr. Iik Arifin Mansurnoor, MA, Ph.D and Dr. JM Muslimin, MA who give a chance to researcher for doing and presenting this research. This research supported by The Graduate School of Islamic Studies UIN Syarif Hidayatullah.

\section{References}

[1] al-Bujairimy, Tuhfah al-Habib 'ala Syarhi al-Khotib, 1st ed., Beirut: Dar al-Kotob alIlmuyah, 1996.

[2] W. al-Zuhaily, al-Fiqh al-Syafi'i al-Muyassar, 1st ed., Damaskus: Dar al-Fikr, 2008.

[3] al-Jauziyyah, Asrar al-Sholah, 1st ed., Cairo: Ibnu al-Islam, 2007.

[4] al-Jailani, Sirr al-Asrar, 3th ed., Damaskus: Dar al-Sanabil, 1994.

[5] 'Ulya, "Implikasi Shalat dalam Membentuk Kepribadian Perempuan," Musawa, vol. X, no. 1, pp. 140-141, 2011.

[6] al-Shabbagh, al-Khusyu' fi al-Shalat, 3th ed., Riyadh: Dar al-Warraq, 1999.

[7] Istianah, "Shalat Sebagai Perjalanan Ruhani Menuju Allah," Esoterik, vol. I, no. 1, pp. 5354, 2015.

[8] Putra, "Tasawuf, Ilmu Kalam, dan Filsafat Islam," al-Adyan, vol. VII, no. 2, p. 94, 2012.

[9] al-Qusyairi, Nahw al-Qulub al-Kabir, 1st ed., Cairo: 'Alam al-Fikr, 1994.

[10] Maulana, "Refleksi Sufistik dalam Nahwu al-Qulub Karya Abu al-Qasim al-Qusyairi,"

Dialogia, vol. XVII, no. 1, pp. 28-29, 2019.

[11] S. Dhaif, Mu'jam Wasith, 4th ed., Cairo: Maktabah al-Syuruq al-Dauliyyah, 2004.

[12] al-Bari, Kawakib al-Durriyyah, 7th ed., al-Haramain, 2011.

[13] M. al-Gholayaini, Jami' al-Durus al-'Arobiyyah, 28th ed., Beirut: al-Maktabah al'Ashriyyah, 1993.

[14] Pransiska, "Konsep I'rob dalam Ilmu Nahwu," al-Mahara, vol. I, no. 1, pp. 75-77, 2015.

[15] al-Imrithi, Nadzam al-Imrithi, Kediri: Madrasah Hidayah al-Mubtadi'in.

[16] al-Shanhaji, al-Ajurumiyyah, Kediri: Madrasah Hidayah al-Mubtadi'in.

[17] al-Andalusiy, Alfiyyah Ibnu Malik, Kediri: Madrasah Hidayah al-Mubtadi'in.

[18] M. Aswad, "The Effect Of Prepositions On Antinomy," Diyala, vol. XXV, no. 1, p. 397, 2015.

[19] Idris, "Atsar Harf al-Jar (Min) al-Ashliyyah fi Istinbath Ma'ani al-Qur'an al-Karim," Arab Journal of Sciences and Research Publishing, vol. I, no. 5, pp. 61-63, 2019.

[20] A. Basith, "Pandangan Tamam Hassan Tentang 'Amil dalam Ilmu Nahwu," Adabiyyat, vol. VII, no. 1, pp. 35-36, 2008.

[21] Sajari, "Keotentikan Ajaran Tasawuf," Dialog, vol. XXXVIII, no. 2, pp. 147-148, 2015.

[22] al-Kuhany, Munya al-Faqir al-Mutajarrid wa Saira al-Murid al-Mutafarrid, Aleppo: Dar al-Haya.

[23] al-Kuhany, Syarh Tarjama bad'i al-Wahyi, 1st ed., Beirut: Dar al-Kutub al_Ilmiyyah, 2002.

[24] Nawawi, Nihaya al-Zain, 1st ed., Beirut: Dar al-Kotob al-Ilmiyah, 2002. 
[25] A. al-Malibary, Fath al-Mu'in, 1st ed., al-Haramain, 2006.

[26] Nawawi, Mirqat Su'ud al-Tasdiq, 1st ed., Kediri: Hidayah al-Thullab.

[27] al-Ghazi, Fath al-Qarib, 1st ed., Dar ihya' al-Kutub al-Arabiyyah.

[28] Mohammad, "Grammatical Classification of Sufi al-Qusyairi al-Sya'rani," JHSC Journal of Historical and Cultural Studies, vol. X, no. 33, p. 231, 2018.

[29] Basyir, "Ilmu Tasawwuf Dalam Menghadapi Tantangan Kemodenan," Qalbu, vol. III, no. 3, p. 64, 2017.

[30] al-Haddad, Risalah Adab Suluk al-Murid, Tarem: Maqam al-Imam al-Haddad, 2012.

[31] al-Iskandary, Allah al-Qashdu al-Mujarrod, 1st ed., Cairo: Maktaba Madbuli, 2002.

[32] al-Iskandary, Taj al-'Arus, al-Haramain. 